\title{
The Communicative Effectiveness Index: Its Use with South African Stroke Patients
}

\author{
Claire Penn and Kelly Milner \\ Department of Speech Pathology and Audiology \\ Peter Fridjhon \\ Department of Statistics \\ University of the Witwatersrand
}

\begin{abstract}
The functional communication of a group of 28 South African stroke patients was examined using the Communicative Effectiveness Index (CETI). It was translated into Afrikaans, Sotho and Zulu and administered to the significant others of 22 aphasic patients with left hemisphere damage and 6 patients with right hemisphere damage. Results were related to the results of standardised language testing and to case history factors such as cultural factors and time since onset. The CETI was readministered in the case of eight of the aphasic subjects after a mean period of six months in order to assess its sensitivity to recovery. Results showed that the CETI seems applicable across different language groups, that it is sensitive to change across time as well as sensitive to the communication disorders resulting from both right and left hemisphere damage. Further it appears to correlate well with overall level of severity. It does not appear to differentiate patients in terms of time since onset. Its potential use as a relatively culture free assessment tool in the South African context is discussed.
\end{abstract}

\section{OPSOMMING}

Die funksionele kommunikasie van 28 Suid Afrikaanse pasiente is deur middel van die Kommunikasie-effektiwiteitsindeks (KEI) ondersoek̂. Die Indeks is in Afrikaans, Sotho en Zulu vertaal en op die familielede van 22 afasie pasiente met linker-hemisfeerskade en 6 pasiente met regter-hemisfeerskade toegepas. Die resultate is, waar moontlik, in verband gebring met die resultate van gestandardiseerde taaltoetse en aspekte in die gevalsgeskiendenis soos kultuur en die tydsverloop sedert die aanvang van die insident. Die KEI is weer na 'n periode van ses maande op 8 van die pasiente toegepas, om sodoende die sensitiwiteit vir herstel te evalueer. Resultate dui aan dat die KEI toepasbaar is op verskillende taalgroepe, en dat dit sensitief is vir herstel sowel as die kommunikasie-probleme as gevolg van beide linker-en regterhemisfeerskade. Dit korreleer goed met die algemene graad van die probleem. Die KEI onderskei egter nie pasiente ten opsigte van die tydsverloop sedert die aanvang van die insident nie. Die potensiele gebruik van die KEI as'n relatiefkultuurvrye evaluasie-instrument in die Suid Afrikaanse konteks, is bespreek.

Certain characteristics of the South African stroke population may be identified as being unique. These characteristics present a challenge to both the clinician and researcher, and often make it difficult and inappropriate to adapt some of the traditional approaches to assessment and treatment to local patients.

'The first factor to consider is that of multilingualism. The majority of aphasic patients in this country are bi- or multilingual (Penn \& Beecham, 1992). Most patients however are tested and treated in their second or third languages as most clinicians are currently unilingual. In addition despite several informal attempts (eg. Semela, 1978) there have been no properly standardised versions of tests developed for aphasia. Probably of even more importance, however, is the fact that the tests are not culture-free. Even for English speaking South African aphasic patients, many of the test items of the aphasia tests currently in use are inappropriate for cultural reasons.

Another difficulty lies in the type of facilities available for the treatment of aphasia. Despite the fact that the causes of aphasia, such as stroke, are amongst the highest in the world in the South African population, the facilities for treatment and rehabilitation are very inadequate (Fritz \& Penn, 1992). The amount of time spent in an acute care hospital is much shorter than in other countries. In addition, there are (with yery few exceptions) no rehabilitation hospitals or facilities available to the patient on discharge. Within the hospital setting, very few patients have access to a range of rehabilitative therapies, except in urban areas. Given that there are many vacant and unfilled posts in state health institutions, it is rare that an aphasic patient in any setting other than an urban one, will be seen by a speech-language therapist. The fact that there are unrealistic medical aid limits, exacerbates the problem, so that most patients after discharge are not able to afford private therapy rates.

Certain sociopolitical factors also have their impact on aphasia rehabilitation. Due to a long history of inequality and educational disadvantage, the majority of aphasic patients in South Africa are economically disadvantaged. Many patients reside a long way from available facilities, and geographical distance and lack of transport are factors to be borne in mind. Further, many patients are poorly educated, either functionally illiterate or barely literate, making the application of for- 
malised tests inappropriate. Finally, high levels of unemployment, break up of family structure, no access to insurance etc, make for a very mobile and inaccessible aphasic population.

The aphasia clinician, working in a large hospital can normally expect to see the patient during the acute phase only. After discharge, unless the patient is resident near the hospital and mobile, it is unlikely that there will be follow- up. 'The burden of rehabilitation thus often lies on the caregivers and those working in the community.

For these reasons, there is an urgent need to re-address some of the basic tenets in aphasia.

There has been a move in recent years towards a societal view of aphasia. This view hinges on the observation that aphasic patients often have many communicative strengths which enable them to function relatively well in a social context, in contrast to their performance on traditional language measures (Aten, 1986; Goldblum, 1985; Holland, 1980; Penn, 1985). This shift in approach is reflected not only in the assessment measures used for aphasia, but also in increased acknowledgment and awareness of the importance of the context of the aphasic patient and on the estimation of the perceived effect of the disability on others in the environment. For example, some recent research has compared spouse and clinician ratings of aphasia. A study conducted in 1976 by Helmick, Watamori and Palmer compared spouse and clinician ratings on the Functional Communication Profile (Sarno, 1975). They found considerable differences between spouse and clinician ratings, with spouses tending to underestimate the severity of the aphasia. This, it was suggested could lead to unrealistic expectations of the spouse. Muller and Code (1983) have also indicated that both spouse and aphasic persons are significantly more hopeful about eventual outcome than aphasiologists. Holland ( 1977 as cited by Zraick \& Boone, 1991) on the other hand suggests that such a finding relates to the clinical biases of the speech therapists in evaluating aphasia. Shewan and Cameron (1984) found that in many instances spouses used in their study were unaware of aphasic-spouses' difficulties, although a better understanding of problems was noted in the groups of subjects receiving treatment than those that were not currently enrolled in speechtherapy. Interestingly no difference in spouse patient agreement across severity was noted.

Much of the disagreement among researchers may relate to differing methodologies of the studies as well as to the type of tool used to measure the impact of aphasia. It is of note, further, that although in recent years patients with right hemisphere lesions have been treated by speech language therapists and have been identified as having considerable social and pragmatic difficulties, no research on spouse attitudes appears to have been undertaken. A tool which has been developed recently which holds the promise of becoming a useful measure of spouse attitude both for aphasic and right hemisphere patients is the Communicative Effectiveness Index (CETI) (Lomas et al., 1989).

The Communicative Effectiveness Index (CETI) was developed in Canada by a group of researchers interested in devising a relevant measure of functional communication for aphasic patients. First described by Lomas et al., 1989, the index was drawn up on the basis of interviews with groups of aphasic patients and their spouses. A series of communication situations was generated from these interviews and through applications to groups of stable and acute patients, a final index of 16 situations was derived (See Appendix 1). The CETI is administered to the spouse (or significant other) of the patients and involves the use of the Visual Analogue Scale (VAS).
The results of the preliminary study by Lomas et al. (1989) suggested that the CETI was both a valid and reliable tool as a measure of communication and an index of improvement as a result of treatment and/ or spontaneous recovery. However, Lomas et al. called for additional research using this tool. Furthermore, the authors pointed out that the CETI is not meant to be a substitute for standard testing, nor a comprehensive test of language functioning. Neither is the CETI meant to discriminate between types of aphasia or act as a predictive tool. It does, however, reflect the severity which the effects of the aphasia have on communicative effectiveness, as perceived by a person in the environment who is likely to experience these effects on an everyday basis.

The potential of the CETI as a tool for use in the aphasic population of South Africa seems particularly good for a number of reasons. Firstly it is based on interviews with aphasic patients and spouses and relates to the communication categories of basic need, health threat, life skill and social skill. As such, these items seem to be less sensitive to cultural and linguistic aspects, to literacy level and to socioeconomic status than many of the other tests/measures currently available. It also appears to be sensitive to the communication problems found in the right hemisphere stroke population. Secondly it is administered to the spouse or caregiver of the patients and is concerned with everyday functional language behaviours. It thus focuses on a societal view of aphasia and identifies areas of strength and weakness relevant to those in the environment of the aphasic patient. For a number of reasons which are outlined above, in the majority of cases, rehabilitation and recovery of function of the aphasic patient is more likely to take place in a home setting, in the context of the family rather than in a coordinated rehabilitation setting. The attitude of the caregivers thus becomes a particularly important element in any consideration of aphasia. 'Thirdly, the method of adminstration is simple, flexible, short and versatile, involving the use of the Visual Analogue Scale which appears not to be dependent on literacy, numeracy level or education of the patient and the family. It is applicable in both the acute and relatively stable/chronic phases of aphasia. The purpose of the study was therefore to explore the use of the CETI within a South African context, in the hope that it will prove a culturally relevant index for the South African aphasic population by being flexible, socially valid and providing the clinician with some therapy guidelines as well as being amenable to a broad community based approach to rehabilitation.

\section{METHOD}

The objectives of the study were as follows:

- To translate the CETI into Sotho, Zulu and Afrikaans

- To administer it to a range of aphasic patients in each of four language groups (English, Afrikaans, Zulu, Sotho)

- 'To administer it to a group of patients with right hemisphere damage

- 'To compare, where possible, results of CE'TI to the results of standardised language testing

- To examine the relationship between scores obtained on the CE'II and overall severity of aphasia

To examine the relationship between performance on the CE'II and certain case history factors, eg. time since onset of the problem and racial/cultural background

- To readminister the CETI, where possible, after a period of time to assess its sensitivity to recovery and/or improvement following therapy

- To determine whether there is any characteristic item differentiation between groups. 
It was hypothesised that:

1. The nature of the aphasic deficit in a group of South African aphasic patients would be highlighted by means of the CETI.

2. There would be a difference between the scores of patients tested on the CETI after a period of recovery.

3 . The patients with right hemisphere damage may show a communicative deficit as highlighted by the CETI.

4. There would be some correlation between the type of standardised test profile that the patient displays and the results on the CETI.

\section{SUBJECTS}

A multicultural group of 28 adult stroke patients was used in this study. The subjects were divided into three groups:

Group A. 14 subjects were diagnosed as aphasic patients in that they had a single episode, cerebral vascular accident of sudden onset and had left hemisphere (LH) damage in the language areas, as confirmed by the report of a neurologist and /or speech language pathologist. This group of patients had a single CETI administered. The mean age of this group was 57 years and the mean time since onset of aphasia was 14 months.

Group B. An additional 8 aphasic subjects, who fulfilled the same criteria as patients in Group A were tested on two occasions (designated B1 and B2). Four members of this group were stable (ie. first tested at more than six months post onset) and four were acute or "recovering" (to use the terminology of Lomas et al.) that is less than six months post onset. The purpose of this was to allow for a comparison with the data of Lomas et al. (1989). The mean number of months between first and second testing for these two groups was 3 months for the acute group and 13 months for the stable group respectively. The mean age of this group was 56 years.

Group C. The remaining six subjects had a communication problem resulting from a right hemisphere (RH) stroke, as determined by the report of a neurologist. These patients were included in the study because the communication effects of right hemisphere damage have been well documented and are sensitive to societal measures of performance such as the CETI. The mean age of these patients was 52.5 years and the mean time since onset was 4 months.

For various reasons outlined in the introduction, the selection of a homogenous group of aphasic patients is particularly difficult in the South African context. Criteria for subject selection were thus restricted to the following: Each subject should have a spouse and/or significant other spending at least three days a week with him/her, (in order to ensure accuracy in filling out the CETI) and each subject should have as a home language one of the following four languages: English, Afrikaans, Zulu or Sotho (as the measure was translated in these languages only). Other factors such as age, gender, educational level, time since onset of the problem and previous therapy were not controlled for.

Details pertaining to the subjects are portrayed in Table 1 . .The age range of the subjects was from 19-82 years. 18 English speaking patients, 3 Afrikaans-speaking patients, 6 Zulu speaking patients and 3 Sotho patients were used in the study. Information pertaining to the spouse or significant other who completed the CETI is also provided in Table 1. Patients were identified by speech therapy departments and clinics in the Johannesburg areas and were tested over a period of two years.

\section{METHOD}

1. Translation of the CETI. The Canadian version of the CETI was translated verbatim into three languages: Afrikaans, Sotho and Zulu. These languages were selected on the basis of their being most commonly used by patients in the area of Johannesburg. Translations were undertaken by first-language qualified speech-language and hearing therapists in the appropriate home language and were checked for accuracy by an additional native speaker and by the Department of African Languages at the University of the Witwatersrand. None of the content of the CETI was altered because the authors of the test (Lomas et al., 1989) have suggested that the items have universal application.

2. Administration of the CETI. The CETI was administered to all the subjects in the following way: The authors provided a broad background to graduate or student therapists who were working with the particular patient. Student therapists were instructed on the use and administration of the CETI in accordance with the directions set out by Lomas et al. (1989). The spouse or significant other was interviewed and informed of the purpose of the study. The CETI was then completed, following a brief discussion of the VAS with the spouse/caregiver.

3. Additional testing. In addition, formalised testing of the patients took place. In most cases a standard aphasia test (eg. the Boston Diagnostic Aphasia Examination (BDAE), Goodglass and Kaplan 1972; the Western Aphasia Battery (WAB), Kertesz 1982) or translated versions thereof were administered over one or two test periods with the patients. The procedure followed the designated instructions in the manual. Formalised testing was not always possible, however, for the following reasons: the patient was still in the acute phase and therefore difficult to test, a translated version of the standard test was not available or the patient had been discharged before standardised testing could be undertaken. In such cases, an informal judgement of type and severity of aphasia was made on the basis of unstandardised assessment tasks (eg. a language sample) and discussion with the therapists of the patients. Where sufficient data were available a severity rating, using the severity rating scale of the Boston Diagnostic Aphasia Examination (Goodglass \& Kaplan, 1980) was also undertaken. The purpose of this testing was to provide some baseline of comparison for the results obtained on the CETI.

4. Follow up testing. For the eight LH patients whom it was possible to follow up, a CETI was readministered (Mean time interval 6 months; range 3 months - 15 months). This time period was selected in order to ensure, as far as possible. that the period of spontaneous recovery was past (Kertesz, 1982). Follow-up testing was done on a previously marked CETI as Lomas et al. suggest, giving the spouses the benefit of seeing where their previous judgement had been (Guyatt, Borman, Townsend \& Taylor 1985). The time interval between the two testing sessions for the repeat group was generally longer than in the case of the Lomas et al. (1989) study.

\section{SCORING METHOD AND ANALYSIS OF DATA}

The scoring of the CETI involves the use of the Visual Analogue Scale. Not only is it assumed to be particularly sensitive to changes in performance over time as Bond and Lader (1974) have suggested, it is also considered relevant for the type of population used in this study as Jacobson (1986) and others have shown that it is not reliant on literacy and numeracy levels. 
Table 1: Subject Characteristics

\begin{tabular}{|c|c|c|c|c|c|c|c|c|}
\hline Ss & Sex & Age & $\begin{array}{c}\text { Time since } \\
\text { onset }\end{array}$ & $\begin{array}{c}\text { First } \\
\text { Language }\end{array}$ & $\begin{array}{l}\text { Result of std } \\
\text { testing }\end{array}$ & Severtiy & Therapy & $\begin{array}{c}\text { Person } \\
\text { Interviewed }\end{array}$ \\
\hline \multicolumn{9}{|c|}{ GROUP A - APHASIC SUBJECTS, SINGLE TESTING } \\
\hline 1 & M & 56 & $3 y ; 2 m$ & Zulu & Expressive & Severe & $\mathrm{Y}$ & Wife \\
\hline 2 & $\mathrm{~F}$ & 46 & $-; 2 \mathrm{~m}$ & Zulu & WAB:AQ 12.5 & Severe & $\mathrm{Y}$ & Nurse-aid \\
\hline 3 & M & 64 & $-; 4 m$ & Soth & WAB:AQ 76.8 & Mild & $\mathrm{Y}$ & Son \\
\hline 4 & M & 41 & $-; 3 m$ & Eng & BDAE: 1 & Severe & $\mathrm{Y}$ & Wife \\
\hline 5 & $\mathrm{~F}$ & 51 & $5 y$ & Eng & WAB:AQ 57 & Severe & $\mathrm{Y}$ & Husband \\
\hline 6 & $M$ & 24 & $1 y: 4 m$ & Eng & CADL: anomic & Mild & $\mathrm{Y}$ & Father \\
\hline 7 & F & 82 & $-; 1 \mathrm{~m}$ & Eng & WAB:AQ 90.4 & Mild & $\mathrm{Y}$ & Daughter \\
\hline 8 & $\mathbf{M}$ & 59 & $-; 8 m$ & Eng & BDAE:1 & Severe & $\mathrm{Y}$ & Wife \\
\hline 9 & F & 70 & $3 y$ & Eng & WAB:AQ 85.7 & Mild & $\mathrm{Y}$ & Husband \\
\hline 10 & $\mathbf{M}$ & 47 & $1 y$ & Eng & WAB:AQ 92.6 & Mild & $Y$ & Wife \\
\hline 11 & $\mathbf{M}$ & 63 & $-; 8 \mathrm{~m}$ & Afr & WAB:AQ 68 & - & $\mathrm{Y}$ & Daughter \\
\hline 12 & $\mathrm{~F}$ & 78 & $-; 1 \mathrm{~m}$ & Eng & WAB:AQ 45 & - & $\mathrm{N}$ & Husband \\
\hline 13 & $\mathbf{M}$ & 58 & - & Eng & WAB:AQ 77 & Mild & $\mathrm{Y}$ & Son \\
\hline 14 & $\mathrm{M}$ & 61 & $3 y$ & Eng & BDAE: 2 & Severe & $\mathrm{Y}$ & Wife \\
\hline \multicolumn{9}{|c|}{ GROUP B - APHASIC PATIENTS WITH REPEAT TESTING } \\
\hline 15 & $\mathrm{~F}$ & 59 & $1 \mathrm{y} ; 3 \mathrm{~m}$ & Eng & WAB:AQ 37.9 & Severe & $\mathrm{Y}$ & Husband \\
\hline 16 & $\mathrm{~F}$ & 57 & $-; 3 \mathrm{~m}$ & Afr & WAB:AQ 46.7 & Mild & $\mathrm{Y}$ & Son \\
\hline 17 & F & 57 & $6 y$ & Eng & WAB:AQ 65.6 & Mild & Y & Husband \\
\hline 18 & $\mathrm{M}$ & 72 & $3 y$ & Eng & - & - & $\mathrm{Y}$ & Wife \\
\hline 19 & M & 52 & $-; 1 \mathrm{~m}$ & Zulu & WAB:AQ 82.8 & Mild & $\mathrm{Y}$ & Brother in law \\
\hline 20 & M & 65 & $-; 5 \mathrm{~m}$ & Soth & WAB:AQ 12.3 & Severe & $\mathrm{Y}$ & Son \\
\hline 21 & $M$ & 53 & $-; 2 m$ & Zulu & WAB:AQ 56.7 & Severe & $\mathrm{N}$ & Wife \\
\hline 22 & $\mathrm{~F}$ & 36 & $-; 9 m$ & Zulu & BIAE:3 & Mild & $\mathrm{Y}$ & Mother \\
\hline \multicolumn{9}{|c|}{ GROUP C - RIGHT HEMISPHERE GROUP } \\
\hline 23 & $\mathrm{~F}$ & 60 & $-; 4 \mathrm{~m}$ & Soth & WAB:AQ 89.5 & Mild & $\mathrm{Y}$ & Wife \\
\hline 24 & M & 61 & $-; 3 \mathrm{~m}$ & Eng & WAB:AQ 89.4 & Mild & $\mathrm{N}$ & - \\
\hline 25 & M & 67 & $-; 1 \mathrm{~m}$ & Eng & WAB:AQ 79.4 & - & - & Cousin \\
\hline 26 & $\mathrm{~F}$ & 69 & $-; 1 \mathrm{~m}$ & Eng & - & Severe & - & Sister \\
\hline 27 & $\mathrm{~F}$ & 39 & $-; 4 \mathrm{~m}$ & Zulu & WAB:AQ 92.8 & Mild & $\mathrm{Y}$ & Mother \\
\hline 28 & $F$ & 19 & $-; 9 \mathrm{~m}$ & Afr & WAB:AQ 79.9 & Mild & $\mathrm{Y}$ & Niece \\
\hline
\end{tabular}

KEY AND EXPLANATION TO TABLE 1

-: Information not available

First Language: English (Eng), Sotho (Soth), Zulu or Afrikaans (Afr)

Aphasia type/score: determined by formal testing using BDAE or WAB where possible, otherwise by informal observation and/or therapist report. WAB AQs reported when available.

Sev: Severity as rated on the severity rating scale of the Boston Diagnostic Aphasia Examination (Goodglass \& Kaplan, 1980) Prev Ther: History of previous therapy (Y: Yes; N: No)

Other: Significant other interviewed 
The position on the scale of each response was calculated by measurement on a 100 millimeter scale and an overall percentage score was thus obtained for each item and for each patient, moved to full decimal point. Scores for each item were calculated and means for each item across the three subjectgroups were calculated.

\section{Statistical Testing}

As the sample sizes were small and the normality of the population questionable, non parametric measures were used to test group differences - namely the Mann Whitney U test and the Wilcoxon matched pairs signed-rank test (Siegel, 1965). Group differences were tested between Groups A, B and C, between Group $A$ and $B$ combined (representing the $\mathrm{LH}$ group) versus Group $\mathrm{C}$, and between the two testing periods of Group B (referred to as B1 and B2).

Statistical testing was also undertaken for the variables of severity, time since onset and linguistic/cultural background, with the LH group (Groups A and B combined). This was done in order to relate the subjects' performance on the CETI to case history factors known to relate to aphasia test performance.

Severity. The overall severity of the aphasia, as measured on a standard test or on the Boston Diagnostic Aphasia Examination severity rating scale (Goodglass \& Kaplan, 1980), was characterised and patients divided into mild versus severe aphasic patients (ie. for Groups A and B). 10 Patients were classified as mild and 9 as severe patients on this scale. The severity level of three of the patients was not possible to assess either because of missing data, or because their classification was equivocal (eg. in the case of conduction aphasia).

Time since onset. The cut off point of six months, which is the period traditionally considered as reflecting a period of spontaneous recovery, was selected (Kertesz, 1983). In Groups A and B combined (that is the LH subjects), ten subjects had a time since onset of less than six months and 11 subjects a time since onset of more than six months.

Linguistic/Cultural Background. Aphasic patients (that is Groups A and B) were split into two groups reflecting their relative racial/cultural background. For the purposes of this study the groups used were White (including English and Afrikaans speakers) and Black (including Sotho and Zulu speakers). The numbers were 7 (Black) and 15 (White) respectively. This split, though acknowledged to be crude, reflects in some way the split created by sociopolitical divisions and rehabilitation services offered in this country to date. An analysis of differences by language was also done in order to ensure that the translation of the CETI did not affect the results obtained.

Item analysis. In order to gain some insight into the specific nature of the communication problems experienced by the subjects in this study, an item analysis was undertaken, using a measure splitting the scores obtained into quartiles. As there were no scores in the bottom quartiles, the first and second quartiles were combined into one catogory, hence deriving the following three ranges: $0-49,50-74$ and $75-100$.

This was done by means of a matrix (see Appendix 2) whereby items that were not consistent across groups were identified. (Inconsistent items were off the major diagonal of the matrix).

This analysis was undertaken for the aphasia group as a whole, and for comparing the two testing sessions for Group B. It was also undertaken for the RH group as well as for the variables of severity, time since onset, and culture, using the aphasic patients (that is Groups A and B).

Sample size prohibited such a breakdown in the case of the RH group (Group C).

\section{RESULTS AND DISCUSSION OF RESULTS}

\section{Results of Statistical Testing}

\section{A. Group Scores on the CETI}

The means of the subjects' scores in each group for each item are presented in Table 2.

This table reveals the following trends:

1. No significant difference exists between the overall scores for Groups A, B1 and C. This confirms that the CETI not only seems sensitive to South African aphasic disorders but also to the problems following right hemisphere damage. The fact that no differences existed between the scores of Groups A and $B$ justifies their combination in certain of the analyses undertaken.

For Group A(LH) a mean score (across all items) was $58.2 \%$ with a range of $35-79 \%$. For Group B (testing period 1) the mean score was $59 \%$ (range $35-77 \%$ ) and for Group $C$ the mean was $70 \%$ ( range $40-86 \%$ ). This was done using the Mann Whitney U test (between A and B1 - $u=k ; N S$; between A and C - $\mathrm{u}=\mathrm{k}$; NS).

2. For Group B, there was a significant difference between the scores obtained for the two testing periods $\{59 \%$ versus $70 \%$ respectively) with a mean improvement of $10.6 \%$ across time (Wilcoxon matched pairs testing, $T=14, p=.05$ ). This was true for both the stable group and the acute group (the mean difference in improvement being 12.5 percent and 8.8 percent respectively). This difference was found to be significant (Mann Whitney $U$ test; $\mathrm{u}=5 ; \mathrm{p}=.05$ ) suggesting that both groups showed improvement on the second testing. The results are, however, somewhat problematic because of the smáll sample size of the two groups and because of the unexpected results in one of the stable patients (Subject 22 ) - who made a very large improvement ( $32 \%$ ) from first to second testing and therefore skewed results for the stable group.

These findings confirm the results of Lomas et al. (1989) and suggest that the CETI is sensitive to changes across time. Not all patients in this group showed a positive change across time however; two subjects' scores went down (subjects 15

Table 2: Mean scores per group across CETI items

\begin{tabular}{|c|c|c|c|c|c|c|c|c|c|c|c|c|c|c|c|c|c|}
\hline CETI item & 1 & 2 & 3 & 4 & 5 & 6 & 7 & 8 & 9 & 10 & 11 & 12 & 13 & 14 & 15 & 16 & Total \\
\hline . Group A & 68 & 59 & 72 & 63 & 79 & 69 & 61 & 65 & 62 & 51 & 55 & 36 & 66 & 37 & 44 & 35 & .58 \\
\hline Group B1 & 66 & 50 & 59 & 64 & 75 & 56 & 59 & 56 & 77 & 55 & 68 & 44 & 67 & 35 & 52 & 53 & 59 \\
\hline Group B2 & 82 & 64 & 79 & 71 & 84 & 73 & 75 & 67 & 94 & 67 & 81 & 50 & 61 & 44 & 62 & $70^{\circ}$ & 70 \\
\hline Group C & 55 & 63 & 86 & 56 & 64 & 53 & 67 & 60 & 73 & 51 & 70 & 52 & 52 & 40 & $56^{\circ}$ & 51 & 70 \\
\hline
\end{tabular}

(Scores are given in percentages) 
and 20 by about 1.1 and $5 \%$ respectively). Looking at the individual subject profiles of these two patients, they were both severe and both were receiving speech-language therapy at the time of the second testing. Thus the negative change in CETI scores might be accounted for in terms of more realistic attitudes having been developed by the spouses. As discussed earlier, research has indicated that spouses whose partners are enrolled in therapy tend to become increasingly aware of the aphasic individual's difficulties (Shewan \& Cameron, 1984).

What is very interesting to note here, is that there is a change in the stable patients, despite claims made that a plateau is reached after a period of time. Changes in long term patients do however persist (eg Sarno, 1975; Aten, 1986) particulary if these changes are measured on functionally relevant test measures. It is therefore not surprising that while the four chronic patients had no significant changes on standard test scores over time, they did reveal differences on the CETIbecoming, perhaps, more "experienced" aphasic persons.

3. The mean score for the right hemisphere group (Group C) was $60.1 \%$ confirming that the right hemisphere patient does have substantial communication deficits frequently not detected by traditional tests (Myers, 1984; Sherratt \& Penn, 1990). Interestingly the extent of the deficit in the RH group is not significantly different from the $\mathrm{LH}$ groups(Mann Whitney test), confirming the severe societal implication that such a defect has for the patient and the need for communication therapy for right-hemisphere brain-damaged subjects.

\section{B. Analysis of Aphasia Patients in Terms of Subject Characteristics}

The results of the analysis undertaken using aphasic subjects from Groups A and B in relation to the variables of severity, time since onset and culture are as follows:

1. Severity. A significant difference in the CETI score was obtained between patients who were classified as mild aphasia (with a mean of $70 \%$ ) and those classified as severe (mean of $51 \%$ ) (Mann Whitney $U ; u=15 ; p<.05$ ). This finding supports the results of Lomas et al. (1989) in sugggesting that the CETI has some validity in that it correlates with other broad measures of severity and therefore has the potential to discriminate accurately between different levels of patients.

2. Time since onset. Ten subjects had a time since onset of less than six months and 11 subjects had a time since onset of more than six months (data on one subject was missing). There was no significant difference found between mean scores of these two groups ( $u=k ; \mathrm{NS}$ ). Once again this may indicate that spouses become more a ware of the difficulties faced by the aphasic person with time.jThus the plight of the acutely aphasic individual may be under emphasized, while the chronic patient may be viewed more realistically.

3. Cultural and language aspects. There was no significant difference found between CETI scores across any of the linguistic groups (English, Afrikaans, Sotho and Zulu) or the two cultural groups (7 Black and 15 White subjects) in terms of overall CETI means in Groups A and B1 ( $u=k ; N S)$. This confirms the hypothesis that the CETI is a relatively culture-free assessment tool, tapping areas of universal relevance to aphasic patients. It also suggests that the translation of the CETI did not appear to affect its reliability .

\section{Item Analysis (Refer Appendix 2)}

1. Item analysis for aphasic patients. The following item shaving a consistent level of severe difficulty across each of the aphasia groups (Group A and B): Item 12 (starting a con- versation with people who are not close family), Item 14 (being part of conversation when it is fast and there is a number of people involved), Item 15 (participating in a conversation with strangers) and Item 16 (describing or discussing something in depth). Of moderate difficulty were: Item 8 (saying the name of someone whose face is in front of him/her) and Item 7 (having one-to-one conversation with spouse). Of least difficulty to the groups was Item 3 (giving yes and no answers appropriately).

Such an analysis confirms that communication situations with high social and cognitive demands are perceived as more impaired after a stroke than others. Such findings also provide directions for intervention in terms of a possible continuum of management contexts.

2. Item analysis differences in retested patients (Appendix 2.2). The differences between items for patients in Group B over the two testing periods was analysed. The assumption underlying this analysis was that certain aspects of communicative behaviour may show a particular sensitivity to change over time. No items deteriorated but interestingly, four items showed an improvement across time in Group B namely: Item 1: (getting someone's attention), Item 3: (giving yes/no answers appropriately), Item 11: (responding or communicating anything without words) and Item 12: (starting a conversation with people who are not close family). The differences in item difficulty between $\mathrm{B} 1$ and $\mathrm{B} 2$ confirm the modality effect for spontaneous recovery described by Lomas and Kertesz (1978), that is that certain modalities (for example comprehension) improve at different rates from others and demonstrate that as the individual interacts with persons of the environment, $\mathrm{s} /$ he becomes more functional in the way that $\mathrm{s} /$ he uses language (Penn, 1983; Aten, 1986 ).

3. Item analysis for the Right Hemisphere group (refer Appendix 2.1). The profile of the RH group was very different in terms of item complexity from the profile of the LH groups. For example, Item 15 (starting a conversation with strangers), which presented the aphasic group with severe difficulties did not seem to be too taxing for the RH patients. This is a strong confirmation of the literature which documents the $\mathrm{RH}$ patients' relative lack of sensitivity to the environment and to the social situation (Millar \& Whitaker, 1983; Myers, 1984). In contrast, understanding writing (Item 13) appeared less difficult for the aphasic patients than for the $\mathrm{RH}$ patients, suggesting that the visuo-spatial deficits of the RH patients may well be interfering substantially with the communicative process.

4. Item analysis by severity (Appendix 2.4). There were several items which differentiated the Mild from the Severe aphasic patient; namely Items $8,9,10,12,13,15$ and 16 . Of particular significance was Item 8 - saying the name of someone whose face is in front of him/her. This item provided maximum differentiation between the mild and the severe aphasic groups, highlighting that it is in the area of lexical specificity that the aphasic individual's language is typically impaired. Anomia is well documented as a primary symptom of the aphasia deficit and it is interesting that it is this item, on a functional measure such as the CETI, that should differentiate mild from severe patients so clearly.

5. Item analysis by Time Since Onset (Appendix 2.5). There was a surprising finding that many items were rated by spouses as being more difficult in the group who were tested more than six months post onset (N12) compared to those who were tested before this cut-off point (N9). Examples of such items include 10 and 14 , (involving conversational skills), 9 (communicating physical problems) and 13 (understanding writing). This finding requires some explanation. It is hypo- 
thesised that the spouse may have become more realistic about the aphasic patient's problems with time. Based on the results of the subjects in Group B, this is not to say that they will not improve across time, but the tendency for early stage aphasic patients to be overrated in terms of their abilities has been documented previously (Helmick et al., 1976; Muller \& Code, 1983) and is confirmed by these results. The difficulties involved in conversing spontaneously, being involved in group situations and in understanding writing may well only emerge as the patient attempts to re-enter pre-morbid social and/or occupational arenas.

6. Item analysis by Culture (Appendix 2.3). The seven Black patients in Groups A and B were considered for separate analysis to determine whether any differences emerged when compared to the group of White patients.

The results of this analysis suggest that overall performance on the CETI is similar for both Black and White subjects. On Item 15, however, Black patients performed better than White (participating in a conversation with strangers) and White patien ts performed better than Black on Item 2 (getting involved in a group conversation) and on Item 5 (indicating understanding of what is being said).

It is not possible to offer an explanation for these findings at present, but they could be suggestive of possible cultural effects of items. It is suggested that these variables require validation through further research.

\section{GENERAL DISCUSSION}

The results of this study suggest the following:

The CETI seems to be a useful tool in the context of South Africa in that it was successfully applied to a multicultural group of South African aphasic patients and reveals results comparable to those found by the original authors of the test on a group of Canadian patients. Equivalent results were obtain ed for aphasic patients regardless of racial, cultural or linguistic background. Further, it appears to be sensitive to effects of severity and to recovery aspects and also highlights the communication deficits remaining after right hemisphere stroke.

Explanations for some of these results seem worth exploring. The fact that the results concur with those of Lomas et al. (1989) confirms the strong societal impact which aphasia has, regardless of culture, language and country of origin. Though attitudes to disability may change from culture to culture, the essence of the aphasic deficit, that is communication disability, must surely be universal in its effect.

The analysis procedure used in this study made possible an investigation of specific item difficulty both within and between groups. Unfortunately Lomas et al. (1989) have not reported the results of their item comparison. It appears however that the present analysis of individual items has yielded some interesting results which may well have therapeutic implications. The fact that the Zulu and Sotho speaking patients, for example, were found to be less affected for group conversation than their White counterparts reflects possible differences in cultural attitudes towards such a disability, as well as suggesting possible directions for the context of rehabilitation. This aspect should be explored in future studies, for if we are to provide adequate aphasia rehabilitation services to the vast Black population of this country, it is imperative that we begin to develop some knowledge of the African understanding of such a disorder.'The method of free interviews to generate items within different cultural contexts, would appear to be a most interesting and valuable area for further research. It should be remembered that the original items selected from a pool of 36 items in the Lomas study were generated by only 14 Canadian aphasic patients. I'here is therefore a strong possibility that some additional items may well be derived in a local study of this nature.

Another dimension for comparison with the Iomas study lies in the results obtained when comparing the eight patients who were tested twice on the CETI. It should be noted that in the Lomas et al (1989) study the CETI was readministered only six weeks after its first administration, and that an improvement was noted in the CE'I'I score only for the recovering (acute) group of subjects, but not in the stable group (more than six months post-onset). However in the present study, (where the mean time interval between test periods was 13 months for the stable group and three months for the recovering group respectively) an improvement was seen in both groups. 'This finding highlights the need to measure the effect of the improvement over a longer period of time than six weeks. In South Africa, few patients receive intensive therapy following the stroke, whereas in the Lomas et al. study, it should be noted that recovering patients were more likely to have received intensive therapy. The findings that stable patients continued to improve, and in contrast to the I.omas et al. study, showed a significant change with time, thus may be accounted for in terms of the different time period used in the studies. The case of Subject 22 in Group B is particularly interesting. A younger subject, she showed a large amount of change, despite the fact that the period traditionally defined as the period of spontaneous recovery had long passed. Not only is the patient relatively young, confirming the writing of I.omas and Kertesz (1978) and others, regarding rate and amount of recovery in younger stroke patients, but she had also received intensive therapy and support from those in her environment and it is felt that the results seen here reflect the value that such stimulation has, well beyond the period of plateau in language skills, in overall communicative effectiveness. The use of the term "recovering" by I omas et al (1989) to describe the patient whose neurological picture is unstable, is perhaps a misnomer, because in contrast to the Lomas study even the stable patients in the present study appear to be "recovering".

The results for the right hemisphere patients are particularly fascinating. The CETI seems to be sensitive to the communication problems that such patients are having. Though there is no difference in overall score on the CETI for these patients and the aphasic patients, the item-analysis has highlighted specific problems in different areas. 'This certainly lends support to the notion that right hemisphere patients need to be referred for communication therapy even if their results on standard measures of language are not significant. This population is very often overlooked in referral to the speech and language therapist. Nevertheless the societal and familial ramifications of this type of disorder may well be amenable to appropriately directed therapy. For example item 5 (indicating understanding of what is being said), which proved to be more difficult for the RH than the LH groups, indicates a need for socially directed compensatory training in such patients.

\section{CONCLUSIONS}

The results of the present study suggest that a measure such as the CETI appears to have some validity on a South African stroke population regardless of cultural and linguistic background. As this measure focuses on the societal and contextual ramifications of aphasia, it becomes a viable alternative to some of the approaches currently being used in assessment as well as providing some guidelines for intervention, not only 
with the aphasic patient but also for the patient with communication problems resulting from right hemisphere damage.

The writers suggest that the ideal South African aphasia test should have the following properties:

* it should be relatively culture free hence applicable to all aphasic patients in South Africa, regardless of linguistic, cultural, social and educational backgrounds

* it should be administered in the patient's home language, preferably by someone who is culturally and linguistically compatible with the patient

* it should be easy to administer and not reliant on factors such as expensive equipment, tape recording of samples (because of the contextual restraint imposed by so many of the testing environments)

* it should be relevant to the context (familial, social and occupational) of the patient

* it should be sensitive to changes in the patient's status and thus be reflective of either spontaneous recovery or of therapy

* it should have desired psychometric properties including reliability and validity

In a preliminary way, it is hoped that this study involving the use of the CETI has shown that such a goal is within our reach. Although no claims can be made about its being comprehensive, diagnostic or definitive, this approach clearly has promise, in that it appears to be both relevant and flexible for local patients.

\section{ACKNOWLEDGEMENTS}

The writers wish to express sincere thanks to the following persons for their assistance during this study: Dilys Jones and Beverley Aron of the Department of Speech Pathology \& Audiology, University of the Witwatersrand ; the Speech Therapists at Johanneshurg, Hillbrow and Coronation Hospitals; Speech-therapy students: Marion Flink, Precious Jenga, Tamar Mehl and Florence Mthoba.

This study was supported by a grant from the Human Sciences Research Council.

\section{REFERENCE LIST}

Aten, J. (1986). Functional communication treatment. In R. Chapey, (Ed.), Language Intervention Strategies in Adult Aphasia. New York: Williams and Wilkins.

Bond, A. \& Lader, M. (1974). The úse of analogue scales in rating subjective feelings. British Joumal of Medical Psychology, 47, $211-218$.

Fritz, V. \& Penn, C. (Eds) (1992). Stroke: Caring and coping Johannesburg Witwatersrand University Press.
Goldblum, G. (1985). Aphasia: A societal and clinical appraisal of pragmatic and linguistic behaviours. South African Journal of Communication Disorders 32, 11-17.

Goodglass, H. \& Kaplan, F.(1972). The assessment of aphasia and related disorders. Philadelphia: J,ea and Febiger.

Guyatt, G., Berman, L., Townsend, M. \& Taylor, D. (1985). Should study subjects see their previous response? Journal of Chronic Diseases,38, 1003-1007.

Helmick, J., Waltamori, T. \& Palmer, J. (1976). Spouses understanding of communication disabilities of aphasic patients. Journal of Speech and Hearing Disorders, 41, 2.38-243.

Holland, A. L. (1980). Communicative abilitics in daily living: A test of functional communication for aphasic adults. Baltimore: University Park Press.

Jacobson, M. C. (1986). Speech intelligibility and articulatory dynamics of reconstructive oral cancer patients. Unpublished doctoral dissertation, University of the Witwatersrand, Johannesburg.

Kertesz, A. (1979). Aphasia and associated disorders, New York: Grune and Stratton.

Kertesz, A.(1980). Western Aphasia Battery. New York: Grune and Stratton.

Lomas, J., Pickard, L., Beste, S., Elbard, H., Finlayson, A. \& Zoghaib, C. (1989). The Communicative Fffectiveness Index: Development and psychometric evaluation of a functional communication measure for adult aphasia. Journal of Speech and Hearing Disorders $54,113-124$

Lomas, J. \& Kertesz, A. (1978). Patterns of spontaneous recovery in aphasic groups: A study of adult stroke patients. Brain and Language, $5,388-401$.

Millar, J. \& Whitaker, H. (1983). The right hemisphere's contribution to language: A review of the evidence from brain damaged subjects. In S.J. Segalowitz (Fd.), Language Functions and Brain Organiza tion. New York: Academic Press.

Muller, D. \& Code, C. (198:3). Psychosocial adjustment to aphasia British Journal of Disorders of Communication, 18, $23-29$.

Myers, P.S. (1984). Right hemisphere impairment. In A. Holland(Ed.) Language disorders in adults, San Diego: College Hill.

Penn, C. (1985). The profile. of communicative appropriateness : A clinical tool for the assessment of pragmatics. South African Journal of Communication Disorders, 32, $18-24$.

Penn, C. \& Beecham, R. (1992). Piscourse therapy in multilingual aphasia: A case-study. Clinical Linguistics and Phonetics, 6,(1). $11-25$.

Sarno, M. T. (1975). The Functional Communication Profile. New York: Institute of Rehabilitative Medicine.

Semela, J. J. (1978). An investigation into the breakdoum of the concordial system of Zulu-speaking aphasics. Unpublished undergraduate research project, University of the Witwatersrand, Johannes burg.

Shewan, C. \& Cameron. H. (1984). Communication and related problems as perceived by aphasic individuals and their spouses.Journal of Communication Disorders, 17, $175-187$.

Sherratt, S. \& Penn, C. (1990). Discourse in a right-hemisphere brain damaged subject. Aphasiologu, 4, (6), $539-560$.

Siegel, S(1965). Nonparametric statistics for the behavioral sciences. New York: Mcgraw-Hill.

Zraik, R. \& Boone, D. (1991). Spouse atitudes towards the person with aphasia. Journal of Speech and Hearing Research, 34, $123-128$.

\section{APPENDIX 1: Communication Situations used in the Communicative Effectiveness Index}

\section{CETI ITEMS}

1. Getting someone's attention

2. Getting involved in group conversations that are about him/her.

3. Giving yes/no answers appropriately.

4. Communicating his/her emotions.

5. Indicating that he/she understands what is being said to him/her.

6. Having coffee time visits and conversations with friends and neighbours

7. Having a one-to-one conversation with you.

8. Saying the name of someone whose face is in front of him/ her.
9. Communicating physical problems such as aches and pains.

10. Having a spontaneous conversation.

11. Responding or communicating anything without words.

12. Starting a conversation with people who are not close family.

13. Understanding writing.

14. Being part of a conversation when it is fast and there are a number of people involved

15. Participating in a conversation with strangers

16. Describing or discussing something in depth. 
APPENDIX 2: Item comparison matrices

(The numbers refer to item numbers of the CETl.)

2.1: Comparison of Item Difficulty for LH (Group A) versus RH (Group B) patients

\begin{tabular}{|c|c|c|c|c|}
\hline & & \multicolumn{3}{|c|}{ Group A } \\
\hline & Mean Score & $<49 \%$ & $50-74 \%$ & $75 \%+$ \\
\hline & $<49 \%$ & 14 & 12 & - \\
\hline Group C & $50-74 \%$ & $15 ; 16$ & $1 ; 2 ; 4 ;$ \\
& & & $6 ; 7 ; 8 ; 9$ \\
$10 ; 11 ; 13 ;$ & $5 ;$ \\
\hline & $75+\%$ & & $3 ;$ & \\
\hline
\end{tabular}

2.2 Comparison of item difficulty on repeat testing for Group B

\begin{tabular}{|c|c|c|c|c|}
\hline & & \multicolumn{3}{|c|}{ Black Subjects } \\
\hline & & $<49 \%$ & $50-74 \%$ & $75+\%$ \\
\hline B2 & $<49 \%$ & 14 & & \\
& $50-74 \%$ & 12 & $2 ; 4 ; 6 ; 7$ & \\
& & & $15 ; 16$ & \\
\hline & $75+\%$ & $1 ; 3 ; 11$ & $5 ; 9 ; 10$ \\
\hline
\end{tabular}

2.3 Comparison of item difficulty for Black vs White subjects

\begin{tabular}{|c|c|c|c|c|}
\hline & & \multicolumn{3}{|c|}{ Black Subjects } \\
\hline & & $<49 \%$ & $50-74 \%$ & $75+\%$ \\
\hline White Subjects & $<49 \%$ & $12 ; 14 ; 16$ & $15 ;$ & \\
& $50-74 \%$ & $2 ;$ & $1 ; 3 ; 4 ; 6$ & $7 ; 8 ; 9 ; 10$ \\
& & & $11 ; 13$ & \\
\hline & $75+\%$ & & 5 & \\
\hline
\end{tabular}

2.4 Comparison of item difficulty for severe vs mild patients.

\begin{tabular}{|c|c|c|c|c|}
\hline & & \multicolumn{3}{|c|}{ Severley Aphasic Subjects } \\
\hline & & $<49 \%$ & $50-74 \%$ & $75+$ \\
\hline \multirow{2}{*}{ Mildly Aphasic Subjects } & $<49 \%$ & $14 ;$ & & $\vdots$ \\
\hline & $50-74 \%$ & $2 ; 10 ; 12 ; 15$ & $1 ; 3 ; 4 ;$ & $6 ; 7 ; 11$ \\
\hline
\end{tabular}

2.5: Comparison of itemdifficulty for subjects tested in stable versus recovering subjects

\begin{tabular}{|c|c|c|c|c|}
\hline \multicolumn{5}{|c|}{$<6 \mathrm{~m}$} \\
\hline & & $<49 \%$ & $50-74 \%$ & $75+\%$ \\
\hline & $<49 \%$ & $12 ; 16 ;$ & $10 ; 14 ; 15$ & 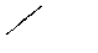 \\
\hline$>6 \mathrm{~m}$ & $50-74 \%$ & 5 & $\begin{array}{r}1 ; 2 ; 3 ; 4 ; \\
6 ; 7 ; 8 ; 11\end{array}$ & $9 ; 13$ \\
\hline & $75+\%$ & & $\therefore$ & \\
\hline
\end{tabular}




\section{Shantom IN-THE-CANAL HEARING AIDS}

with Acoustimed's exclusive "ANTI-FEEDBACK" TECHNOLOGY

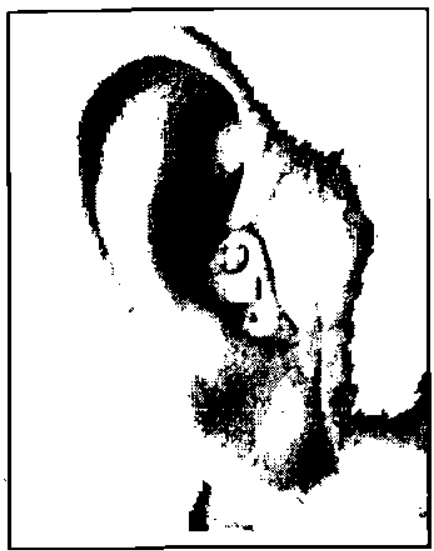

\section{UNLIMITED VENTING WITHOUT WHISTLING}

MORE USABLE GAIN THAN BEHIND-THE-EAR AIDS

USER-CONTROLLED NOISE REDUCTION

EASILY HANDLED BATTERY DRAWER

The acoustic advantages of In-The-Canal hearing aids are well known.

However, until now their use has been limited by acoustic feedback which causes oscillation (whistling). Acoustimed has developed a technique for controlling the phase response of hearing aids to prevent oscillation. Full details are a trade secret but results are spectacular.

We can now make In-The-Canal hearing aids that have more USABLE gain than Behind-The-Ear models and they do not oscillate regardless of how large we make the vent. With the Phantom Model AFP (power) version it is possible to correct nerve deafness with high frequency loss as great as $90 \mathrm{~dB}$.

The Phantom Models AF and AFP have a simple but effective noise control. When the volume is turned down low frequency noise is reduced more than the essential high frequencies. This unique feature has the effect of improving the signal-to-noise ratio in noisy conditions.

Because of the microphone position Phantom hearing aids havè better high frequency performance than Behind-The-Ear models and since there is no tubing they are more efficient and have a smoother frequency respunse. Previously In-The-Canal hearing aids could be used only for mild hearing loss due to feedblack problems. With the new Phantom hearing ' aids there are LESS feedback problems than with Behind-The-Ear models. This allows us to make Phantom aids which work better than many Behind-The-Ear PP hearing aids.

Phantom hearing aids are made in 3 basic models. The approximate fitting range is illustrated in this diagram. Performance is

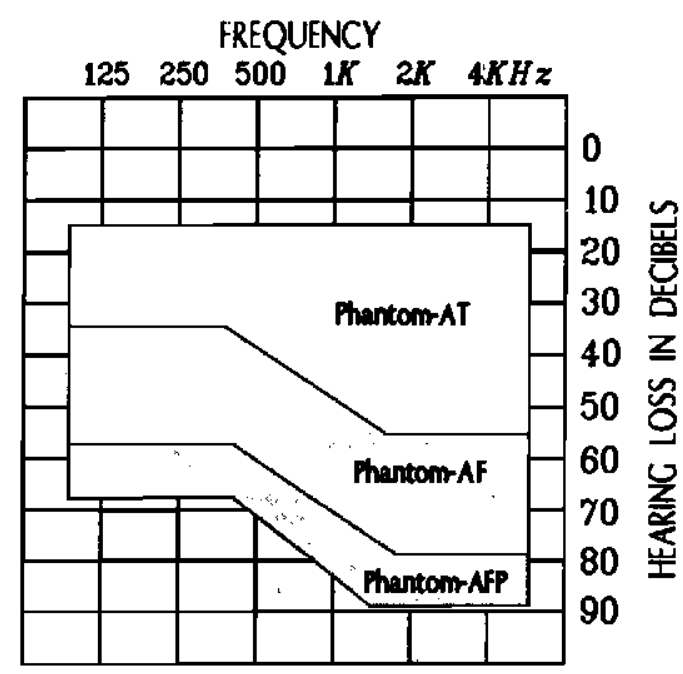
controlled by transducer selection.

\section{ACOUSTIMED HEARING SERVICES}




\section{INFORMATION FOR CONTRIBUTORS}

The South African Journal of Communication Disorders publishes theoretical and philosophical with research, and critically evaluative of human communication conceptual issues dealing with aspects ing; and policy. The South African Journal of Communication Disorders will not accept
material which has been published elsewhere or that is currently
under review by other publications.

\section{MANUSCRIPT STYLE AND REQUIREMENTS}

Manuscripts should be accompanied by a covering letter providing the author's address and telephone numbers. All contributions are rethe American Psychological style specified in the Publication Manual of with complete internal con Assoc. (3rd ed., 1983) (APA Pub. Man.) quality type-written manuscripts with copies of triple-spaced high margins should be submitted They with numbered pages, and wide identical disc copies of the They should be accompanied by TWO extension .wp5); (2) in ASCI Cad (1) in Wordperfect 5.1 (with an names should include the first codes (with an extension asc). Fileable keyword or abbreviation author's initials and a clearly identifithe last line of the last pag thereof and should be typewritten on purposes only).

As a rule, contributions should not exceed much more than 25 pages, warranted. The fapers will be accepted if the additional length is article, name of author(s) $T$ TWO copies should contain the title of the accordance with the APA and institutional affiliation (or address). In NOT required to $A P A$ Pub. Man. style $(1833$, p. 23) authors are copies, the first page should contain only the In the remaining two all copies, should contain contain only the title. The second page of English and Afrikants only an abstract (100 words), written in seas contributors. Major headings wherts will be provided for overorder of METHOD ACKNOWLEDGEMENTS be indented.

TABLES AND FIGURES which should be prepared on separate the copies sent initially. should be copied for review purposes and only used for publication howigures, graphs, and line drawings that are quality white paper, but these will originals, in black ink on good author has been notified of the will not be required until after the appearingon these should of the acceptance of the article. Lettering ing for a $50 \%$ reduction in printing and professionally done, allowtypewritten on the illustration. On no account should lettering be appear below it and should not Any explanation or legend should titles of tables, which appear above included in the illustration. The should be concise but explanatory. Both should be numbered in Arabic allowed, will be at the discretion

\section{REFERENCES}

References should be cited in the text by sumame of the author and the date, e.g., Van Riper (1971). Where there are more than two authors after the first occurrence, et al. after the first author will suffice, except authors should when et al. may be used from the start. The names of all strict alphabetical order in Reference List, which should be listed in references should brder in triple spacing at the end of the article. Al ces, (APA Pub. Man. 1983, p.13). List, including secondary sourjournals may be used (see p.13). Only acceptable abbreviations of List of Scientific Periodicals). The num exceed much more the

\section{EXAMPLES} Locke, J.L. (1983). Clinical psychology: The explanation and treat-
ment of speech sound disorders. J. Speech Hear. Disord., 48, 339-
341.

Penrod, J.P. (1985). Speech discrimination testing. In J. Katz(Ed.) Wilkins.

Davis, G.A. \& Wilcox, M.J. (1985). Adult aphasia rehabilitation Applied pragmatics. San Diego, CA: College-Hill.

\section{EDITING}

Acceptable manuscripts may be returned to the author for revision. Additional minor changes may also be made at this stage, but a note on required. The paper is the ging each alteration made by the author, is final editing for style, clarity returned to the editorial committee for

REPRINTS: 10 reprints without covers will be provided free of
charge.

DEADINNE FOR CONTRIBUTIONS: the preferred ! 31st May each year, but papers will be the preferred date is the arrangement.

QUERIES, CORRESPONDENCE \& MANUSCRIPTS: should be addressed to The Editor, South African Journal of Communication DisBox 31782, Braamfontein, 2017, Souge-Hearing Association, P.O 


\section{INLIGTING VIR BYDRAERS}

Die Suid-Afrikaanse Tydskrif vir Kommunikasieafwijkings publiseer verslae en artikels wat gemoeid is met navorsing, of handel oor krities evaluerende, teoretiese en filosofiese konseptuele kwessies wat oor menslike kommunikasie en kommunikasieafwykings; diensverskaffing; opleiding en beleid gaan.

Die Suid-Afrikaanse Tydskrif vir Kommunikasieafwykings sal nie artikels aanvaar wat reeds elders gepubliseer is, of wat tans deur ander publikasies oorweeg word nie.

\section{MANUSKRIP STYL EN VEREISTES:}

Manuskripte behoort deur 'n dekkings brief vergesel te word wat die skrywer se adres en telefoonnommers bevat. Daar word van alle bydraes verwag om die styl, soos gespesifiseer is in die "Publication Manual of the American Psychological Assoc. (3rd ed., 1983) (APA Pub. Man."), nougeset te volg met volledige interne ooreenstemming. Manuskripte moet getik, van hoë gehalte en in drievoud spasiëring met wye kantlyne wees. Vier kopieë van die manuskrip moet verskaf word. TWEE hiervan moet identiese skyfkopieë van die artikel wees; (1) in "Wordperfect" 5.1 (met 'n uitbreiding .wp5); (2) in ASCII kodes met 'n uitbreiding .asc). Leêrname behoort die eerste skrywer se voorletters en' $n$ duidelike identifiseerbare sleutelwoord of afkorting daarvan in te sluit en moet op die laaste lyn van die laaste bladsy van die verwysingslys getik word (slegs vir naslaan doeleindes).

As 'n reël moet bydraes nie 25 bladsye oorskry nie, maar langer artikels sal aanvaar word indien die addisionele lengte dit regverdig. Op die eerste bladsy van TWEE van die afskrifte moet die titel van die artikel, naam van die skrywers(s), en instansie (of adres) verskyn. In ooreenstemming met die "APA Pub. Man." se styl word daar NIE van skrywers verwag om enige kwalifikasies te verskaf nie. Op die eerste bladsy van die twee oorblywende afskrifte moet slegs die titel van die artikel verskaf word. Die tweede bladsy van alle afskrifte moet slegs'n opsomming (100 woorde) in beide Engels en Afrikaans bevat. Afrikaanse opsommings sal vir buitelandse bydraers voorsien word. Hoofopskrifte moet, waar van toepassing, in die volgende volgorde verskaf word: METODE, RESULTATE, BESPREKING, GEVOLGTREKKING, ERKENNINGS en VERWYSINGS. Alle paragrawe moet ingekeep word.

TABELLE EN FIGURE wat op afsonderlike bladsye (een bladsy per tabel/illustrasie) moet verskyn! moet vir referent doeleindes gekopieër word en slegs die kopieë moet inisieel verskaf word. Figure, grafieke en lyntekeninge wat vir publikasie gebruik word, moet egter oorspronklike weergawes wees en moet in swart ink op wit papier van 'n hoë gehalte wees. Die oorspronklikes sal slegs verlang word nadat die artikel vir publikasie aanvaar is. Letterwerk wat op bogenoemde verskyn moet eenvormig wees, professioneel gedoen word en daar moet in gedagte gehou word dat dit leesbaar moet wees na'n $50 \%$ verkleining in drukwerk. Letterwerk by illustrasies moet onder geen omstandighede getik word nie. Verklarings of legendes moet nie in die illustrasie nie, maar daaronder, verskyn. Die opskrifte van tabelle (wat boaan verskyn), en die onderskrifte van figure, (wat onderaan verskyn), moet beknop, maar helderend wees. Numering moet deur middel van
Arabiese syfers geskied. Tabelle en figure moet in die volgorde waarin hulle verskyn, genommer word. Die aantal tabelle en illustrasies wat ingesluit word, word deur die Redakteur bepaal (gewoonlik nie meer as 6 nie).

\section{VERWYSINGS}

Verwysings in die teks moet voorsien word van die skrywer se van en die datum, b.v., Van Riper (1971). Wanneer daar egter meer as twee skrywers is, moet daar na die eerste verskaffing van al die outeurs, van "et al." gebruik gemaak word. In die geval waar daar egter ses of meer outeurs ter sprake moet "et al." van die begin af gebruik word. Al die name van die skrywers moet in die Verwysingslys verskyn wat aan die einde van die artikel voorkom. Verwysings moet alfabeties in trippel spasiering gerangskik word. Al die verwysings moet in die Verwysingslys verskyn, insluitende sekondêre bronne, ("APA Pub. Man." 1983 , p. 13). Slegs aanvaarbare afkortings van tydskrifte se titels mag gebruik word, (sien "DSH ABSTRACTS, October"; of "The World List of Scientific Periodicals"). Die aantal verwyings moet nie meer as 25 oorskrei nie, tensy dit geregverdig is.

\section{LET OP DIE VOLGENDE VOORBEELDE:}

Locke, J.I. (1983). Clinical psychology: 'The explanation and treatment of speech sound disorders. J. Speech Hear. Disord., 48, 339-341.

Penrod, J.P. (1985). Speech discrimination testing. In J. Katz (Ed.), Handbook of clinical audiology (3rd ed.). Baltimore: Williams \& Wilkins.

Davis, G.A. \& Wilcox, M.J. (1985). Adult aphasia rehabilitation: Applied pragmatics. San Diego, CA.: College-Hill.

\section{REDIGERING}

Manuskripte wat aanvaar is, mag na die skrywer terruggestuur word vir hersiening. Addisionele kleiner veranderinge mag ook op hierdie stadium aangebring word, maar'n nota ter aanduiding van alle veranderinge wat op die manuskrip voorkom, moet verskaf word. Die artikel word dan aan die redaksionele komitee vir finale redigering van styl, duidelikheid en konsekwentheid teruggestuur.

HERDRUKKE: 10 herdrukke sonder omslae sal gratis aan die outeurs verskaf word.

SLUITINGSDATUM VIR BYDRAES: Bydraes word verkieslik teen 31 Mei elke jaar verwag, maar artikels sal nog tot 31 Julie vir aanvaarding oorweeg word.

NAVRAE, KORRESPONDENSIE EN MANUSKRIPTE: moet geadresseer word aan

Die Redakteur, Die Suid-Afrikaanse Tydskrif vir Kommunikasieafwykings, Die Suid-Afrikaanse Spraak-Taal-Gehoor Vereeniging, Posbus 31782 , Braamfontein, 2017, Suid Afrika. 